\title{
Kariery naukowe kobiet na Wydziale Lekarskim USB w Wilnie w okresie międzywojennym (1919-1939)
}

Słowa kluczowe: kobiety, kariera, studia medyczne, II Rzeczpospolita

\section{Wstęp}

Po I wojnie światowej na ziemiach polskich nastąpił czas swoistej nobilitacji pozycji kobiet nie tylko w zakresie nabywania praw wyborczych, ale także realizacji ich dążeń: zdobywania uprawnień zawodowych, uzyskiwania stosownych kwalifikacji. Czas ten skrótowo określa się nawet mianem pewnego „pędu kobiet” po wiedzę ${ }^{2}$ i starań o rozwój karier naukowych.

Problem ten pragnę ukazać na przykładzie Wydziału Lekarskiego uczelni wileńskiej, jednego z kierunku studiów funkcjonującego tam od 1919 r. Kierunku - przypomnijmy - obwarowanego jeszcze u schyłku XIX w. w przypadku kobiet różnymi obostrzeniami, a przynajmniej wybór ten interpretowano jako co najmniej pewną niestosowność 3 .

1 Prezentowane treści są cząstkowym efektem badań dotyczących Uniwersytetu Stefana Batorego w Wilnie prowadzonych w latach 2014-2015, i przygotowywanej na ten temat szerszej monografii. Badania te prowadzone są pod kierunkiem prof. prof. Anny i Mirosława Supryniuków z Uniwersytetu Mikołaja Kopernika w Toruniu.

2 J. Kolbuszewska, Kobiety $w$ nauce - akademicki awans polskich historyczek wczoraj i dziś, „Sensus Historiae” 2015, t. XIX, z. 2, s. 115.

3 J. Mackiewicz, Członkowie Towarzystwa Lekarskiego Warszawskiego w latach 1820-1914, [w:] Z. Podgórska-Klawe (red.), Towarzystwo Lekarskie Warszawskie 18202005, Warszawa 2005, cz. I, s. 398-399; D. Jołkiewicz, Kobiety w naukach medycznych wczoraj i dziś, „Nauka i szkolnictwo wyższe” 2011, t. 38, nr 2, s. 37-39. 
Zagadnienie kariery naukowej kobiet na Wydziale Lekarskim USB w latach 1919-1939 można ukazać na podstawie analizy dokumentacji sprawozdawczej opublikowanej i zgromadzonej w archiwach wileńskich i warszawskich, w tym też w Zbiorach Specjalnych Głównej Biblioteki Lekarskiej (Zb. Spec. GBL). Inne materiały dotyczące poszczególnych osób związanych z tym Wydziałem można było wykorzystać, ze względu na ich szczątkowość, tylko w niewielkim stopniu. Brak jest np. biogramów czy nawet życiorysów większości absolwentek - lekarek czy farmaceutek, które mogłyby swą treścią umożliwić uzupełnienie danych dotyczących ich naukowego czy nawet zawodowego rozwoju. Dotarcie do informacji np. przez czasopiśmiennictwo zawodowe jest niezwykle trudne, a czasem zawodne. Zatem na tym etapie poszukiwań będzie to jedynie próba ukazania czy zasygnalizowania problemu z uwypukleniem pewnych danych statystycznych, które wymagają jednak dalszych badań i weryfikacji.

\section{Kobiety na Wydziale Lekarskim uczelni wileńskiej - pochodzenie społeczne i rekrutacja}

Reaktywowanie po prawie 100 latach uczelni wileńskiej następowało stopniowo, począwszy od 1919 r. Proces ten był bowiem niezwykle złożony i trwał kilka lat, przerywany okolicznościami, które nie sprzyjały rozwojowi uczelni. Stanowiły je działania wojenne roku 1920, a także czasy późniejszych niepokojów. Pomimo trudności dotyczących miasta czy tworzonej uczelni poszczególne wydziały, w tym te o kierunku lekarskim i farmaceutycznym, były rozwijane i stawały się miejscem zdobywania wiedzy i uprawnień zawodowych ówczesnej młodzieży, wywodzącej się z całego obszaru Polski, w dużym stopniu z ziem wschodnich, po części też z zagranicy. Studiowali tu np. Łotysze, mniej licznie Litwini, także Rosjanie czy Czesi. W przypadku oddziału farmaceutycznego byli to głównie Polacy, aczkolwiek w pojedynczych przypadkach także Litwini. Nie można jednak zapominać także o mniejszościach narodowych, wśród których poważną część (przynajmniej na kierunku lekarskim) stanowili Żydzi (w tym i kobiety), łącznie blisko $35 \%$, pod koniec lat 20. XX w., tj. 10 lat później, prawie $21 \%$.

${ }^{4}$ Por. Skład uniwersytetu w roku akademickim 1929-1930, Wilno 1930; Skład uniwersytetu w roku akademickim 1930/1931, Wilno 1931; Skład uniwersytetu w roku akademickim 1931/1932, Wilno 1932; Skład uniwersytetu w roku akademickim 1932/1933, Wilno 1933; Skład uniwersytetu w roku akademickim 1935/1936, Wilno 1936, Skład uniwersytetu w roku akademickim 1936/1937, Wilno 1937; B. Urbanek, Mniejszości narodowe na Wydziale Lekarskim Uniwersytetu Stefana Batorego w Wilnie (lata 1919-1939), „Rocznik Stowarzyszenia Naukowców Polaków Litwy (SNPL)” 2017, t. 17, s. 47-51. 
Kariery naukowe kobiet na Wydziale Lekarskim USB w Wilnie...

Pochodzenie społeczne kandydatów było dość zróżnicowane. $\mathrm{W}$ wykazie $\mathrm{z}$ końca lat 20 . w zakresie proweniencji przyszłych lekarzy znajdujemy kategorie: właścicieli ziemskich, posiadaczy gospodarstw rolnych ${ }^{5}$, zakładów wytwórczych, nieruchomości, kupców, rzemieślników, adwokatów, wojskowych, lekarzy i inne grupy środowiska medycznego (dentysta, aptekarz, felczer), nauczycieli, drobnych urzędników, ale też będących na własnym utrzymaniu - bez rodziny czy nawet zobowiązanych do materialnego ich wspomagania. Nierzadko zaobserwować można było dążenie do podtrzymania tradycji zawodu lekarza. Przewijał się zatem wśród tej akademickiej zbiorowości cały skład społeczny i zawodowy. Dominowały jednak, przynajmniej w podanym okresie, dzieci właścicieli gospodarstw rolnych, urzędników, lekarzy, nauczycieli, ale i wywodzący się ze środowisk zubożałych nawet utrzymujących, jak już wspomniano, rodzinę $e^{6}$ Inna sytuacja w tym zakresie panowała w grupie przyszłych farmaceutów na przełomie lat 20. i 30. XX w., gdzie przeważali przedstawiciele tzw. średnich grup społecznych: właścicieli drobnych zakładów, nieruchomości, często aptek, sklepów, kupcy, w mniejszym stopniu lekarze - dentyści, felczerzy. Ponadto także grupa - co prawda mniej liczna - pozostających na tzw. własnym utrzymaniu ${ }^{7}$.

Do 1927 r. przyjmowanie kandydatów na kierunek lekarski odbywało się wedle wewnętrznego limitu, ustalanego każdorazowo przez Radę Wydziału. Pułap przyjęć kształtował się od 100 kandydatów w pierwszym roku funkcjonowania Wydziału Lekarskiego do 130 w kolejnym, a nawet $150 \mathrm{w}$ następnych latach ${ }^{8}$. Od roku akademickiego $1927 / 1928$ ograniczony został do 120 osób i od tego czasu był już stały. Od 18 czerwca 1929 r. określano go mianem numerus clausus ${ }^{9}$.

W przypadku kandydatów na farmaceutów do roku akademickiego $1923 / 1924$ pułap ten wyznaczono na 40 osób $^{10}$, po okresowym wzroście, a następnie pewnych wahnięciach, utrzymywał się przeciętnie na poziomie $40-45$ osób kwalifikowanych na pierwszy rok. Limitowa-

${ }^{5}$ Tutaj jednak brak rozgraniczenia i opisu szczegółowych różnic tych dwóch grup związanych z prowadzeniem gospodarki na roli.

${ }^{6}$ Por. Lietuvos centrinis valstybes archywas w Wilnie, dalej LCVA sygn.175/10 II ca/22: tamże 175/10/II ca/60.

7 Por. LCVA, sygn. 175/10 II ca/61.

${ }^{8}$ S. Trzebiński, Wydziat Lekarski Uniwersytetu Stefana Batorego, w latach 19191929, [w:] Księga pamiatkowa ku uczczeniu CCCL rocznicy założenia i X wskrzeszenia Uniwersytetu Wileńskiego, t. II. Dziesięciolecie 1919-1929, Wilno 1929, s. 13, 391-392.

${ }^{9}$ Tamże, s. 402.

${ }^{10} \mathrm{~W}$ pierwszym roku studiów na 40 słuchaczy 8 było tzw. zwyczajnych, a 36 tzw. nadzwyczajnych. 
Tabela 1. Studentki na kierunku lekarskim w latach 1919-1923

\begin{tabular}{|c|c|c|c|}
\hline Lata & $\begin{array}{c}\text { Łączna liczba } \\
\text { studentów }\end{array}$ & $\begin{array}{c}\text { Liczba } \\
\text { studiujacych } \\
\text { kobiet }\end{array}$ & $\begin{array}{c}\text { Procentowy } \\
\text { udział }\end{array}$ \\
\hline $1919 / 1920$ & 112 & 48 & $43 \%$ \\
\hline $1920 / 1921$ & 166 & 60 & $36 \%$ \\
\hline $1921 / 1922$ & 321 & 111 & $35 \%$ \\
\hline $1922 / 1923$ & 413 & 142 & $34 \%$ \\
\hline
\end{tabular}

Źródło: K. Karaffa-Korbutt, Działalność naukowa i pedagogiczna USB z lat 1919-1929, Wilno 1931.

nie przyjęć obowiązywało aż do czasów reorganizacji tego kierunku nauczania, który nastąpił w latach 30 . XX w. ${ }^{11}$

Podkreślić jednak należy, że w początkowych latach istnienia uczelni, czyli w latach 20., brak było odgórnie wyznaczonego progu w rekrutacji na studia, uwzględniającego w przyjęciach rozdział kandydatów wedle parametrów takich, jak np. płeć czy nawet narodowość. Dotyczy to wszystkich medyków: kandydatów do zawodu lekarza czy aptekarza. Aczkolwiek statystyczny podział na płeć $\mathrm{z}$ pierwszych lat funkcjonowania uczelni pojawia się chociażby w opracowaniu prof. Kazimierza Karaffa Korbutta ${ }^{12}$, opublikowanym w roku $1931^{13}$, co może świadczyć o gromadzeniu tego rodzaju danych. Dodać warto, że w powszechnym mniemaniu uważa się, że kobiety - w pierwszych latach, w czasie trwających jeszcze działań wojennych - były na wydziałach lekarskich grupą dość liczną, chociaż nie dominującą ${ }^{14}$. Znajduje to, jak się okazuje, potwierdzenie w przytoczonym już opracowaniu K. Karaffa-Korbutta, gdzie wedle zamieszczonych danych w roku 1919/1920, czyli w pierwszym roku funkcjonowania Wydziału, studentki na kierunku lekarskim stanowiły 43\% wszystkich uczących się tam. Trzy lata później, w roku akademickim 1922/1923, sytuacja uległa zmianie i już ich obecność

${ }^{11}$ Tamże, s. 400.

${ }^{12}$ Kazimierz Wacław Karaffa-Korbutt (1878-1935) - profesor, kierownik katedry i zakładu higieny, m.in. członek PAU, TNW, redaktor „Archiwum Higieny”. L. Zembrzuski, Zmarli członkowie: Śp. Kazimierz Wacław Karaffa-Korbutt (1878-1935) [nekrolog], „Rocznik Towarzystwa Naukowego Warszawskiego” 1935, nr 28, s. 99-102.

${ }^{13}$ Zauważyć zatem można, że informacje te były jednak gromadzone. Aczkolwiek brak jest danych dotyczących mniejszości narodowych . Por. K. Karaffa-Korbutt, DziaŁalność naukowa i pedagogiczna USB z lat 1919-1929, Wilno 1931.

${ }^{14}$ Zjawisko to $\mathrm{w}$ tym czasie występowało też na Uniwersytecie Warszawskim. Nawet, jak twierdzi W. Karaffa-Korbutt, przekraczając podany stan. Tamże, s. 582. 
potwierdzona została tylko w $34 \%$, czyli był to blisko $10 \%$ spadek ich udziału w edukacji na tym kierunku w Wilnie ${ }^{15}$.

U schyłku lat 20. wprowadzany numerus clausus ograniczał w dalszym ciągu liczbę przyjmowanych kobiet na kierunek lekarski (prócz limitowania kandydatów narodowości żydowskiej). Wspomnieć warto, że pewnym przeciwnikiem uniwersyteckiego kształcenia kobiet był prof. Stanisław Pigoń, rektor USB (w latach 1926-1928). Na konferencji rektorów 24 kwietnia 1927 r. w Poznaniu stwierdził, że przy przekroczeniu liczby $70 \%$ przyjętych kobiet na studia istnieje groźba, jak się wyraził, zniewieściałości kształcenia ${ }^{16}$. Być może z powodu podobnych poglądów, a i zapadłych później postanowień na uczelni, procent kwalifikowanych kobiet na studia lekarskie w Wilnie oscylował pod koniec lat 20 . w granicach $25 \%$. Kryterium to było odtąd w miarę przestrzegane, chociaż pięć lat później, czyli w roku akademickim $1935 / 1936$, zostało zaniżone i wynosiło $27 \%$ przyjmowanych na studia. Stało się ono wtedy najwyższym procentowym wskaźnikiem dla tej grupy studiujących. Jednak jeszcze na początku lat 30., w czasach postępującego kryzysu gospodarczego, szczególnie w roku akademickim 1931/1932, odsetek kwalifikowanych kobiet na Wydział Lekarski USB został obniżony do $23 \%$. Wydaje się, że procedury tej dokonano celowo, aby zwiększyć możliwości studiowania młodzieży męskiej ${ }^{17}$. Ogólnie jednak zakłada się, że średnio kobiety w medycynie stanowiły 25\% ogółu kadry lekarskiej (dane z 1937 r.) ${ }^{18}$.

Podany poniżej, a według niektórych badaczy określony jako średni, procent zawodowego udziału kobiet $\mathrm{w}$ medycynie dotyczył nie tylko lekarzy, ale także aptekarzy, co może dziwić, a i wart jest sprawdzenia ${ }^{19}$, gdyż w przypadku studiów farmaceutycznych na USB procentowa liczba kobiet przyjętych mogła nawet przekraczać $50 \%$. Potwierdzają to ustalenia K. Koraffa-Korbutta, który uważa, że w roku akademickim 1928/1929 stosunek studiującej młodzieży obojga płci na tym kierunku kształtował się jak $1: 1^{20}$. W następnym roku akademickim osiągnął on wskaźnik prawie $70 \%$ studiujących kobiet ${ }^{21}$.

${ }^{15}$ K. Karaffa-Korbutt, dz. cyt., s. 579.

${ }^{16}$ Protokót konferencji rektorów szkót akademickich odbyty w Poznaniu w dn. 23 i 24 IV 1927, [w:] L. Zembrzuski (red.), Konferencje rektorów szkót akademickich w Polsce w latach 1919-1931. Protokoty narad, uchwaty i memoriaty, Warszawa 1932, s. 119.

17 Por. poniżej tabela 2.

${ }^{18}$ D. Jołkiewicz, dz. cyt., s. 40.

${ }^{19}$ D. Jołkiewicz, dz. cyt.

${ }^{20} \mathrm{~K}$. Koraffa-Korbutt, dz. cyt., s. 512.

${ }^{21}$ W. Jakowicki, Sprawozdanie z Wydziału Lekarskiego USB 1929/1930, „Pamiętnik Wileński Towarzystwa Lekarskiego” 1930, R. V, z. 4-5, s. 384; K. Opoczyński, Sprawoz- 
Dodać jednak należy, że dokonać możemy porównania tylko na przestrzeni dwóch lat kształcenia uniwersyteckiego: 1929/1930 i 1930/1931. Po tym czasie miała miejsce likwidacja oddziału farmaceutycznego i przygotowywano się do nauczania już w nowym systemie. Procesowi temu towarzyszyło ogólne obniżenie przyjmowanych na studia kandydatów. Postępowały także inne zmiany w zakresie kwalifikacji na studia, wprowadzono też kryterium merytoryczne decydujące o przyjęciu na studia' ${ }^{22}$.

Tabela 2. Studenci kierunku lekarskiego USB w latach 1929-1938 z podziałem na płećc ${ }^{23}$

\begin{tabular}{|c|c|c|c|c|}
\hline $\begin{array}{c}\text { Rok } \\
\text { akademicki }\end{array}$ & Mężczyźni & Kobiety & $\begin{array}{c}\text { Razem } \\
\text { studiujących }\end{array}$ & $\begin{array}{c}\text { Procentowy } \\
\text { udział kobiet }\end{array}$ \\
\hline $1929 / 1930$ & 489 & 164 & 653 & 25,11 \\
\hline $1930 / 1931$ & 498 & 179 & 677 & 26,44 \\
\hline $1931 / 1932$ & 548 & 165 & 713 & 23,14 \\
\hline $1932 / 1933$ & 538 & 168 & 706 & 23,75 \\
\hline $1933 / 1934$ & 537 & 170 & 707 & 24,04 \\
\hline $1934 / 1935$ & 524 & 179 & 703 & 25,46 \\
\hline $1935 / 1936$ & 513 & 191 & 704 & 27,13 \\
\hline $1936 / 1937$ & 515 & 190 & 705 & 26,45 \\
\hline $1937 / 1938$ & 547 & 189 & 736 & 25,67 \\
\hline
\end{tabular}

Źródło: por. przypis nr 20.

danie Wydziału Lekarskiego USB za rok 1930/1931, „Pamiętnik Wileński Towarzystwa Lekarskiego" 1931, R. VI, z. 5, s. 415.

${ }^{22}$ Informacja o wpisach $i$ warunkach studiów w Uniwersytecie St. Batorego w Wilnie, [w:] XV spis wykładów na trzy trymestry w roku akademickim 1937/1938, Wilno 1938, s. 3; K. Koraffa-Korbutt, dz. cyt., s. 587.

${ }^{23}$ Według danych pierwszego kursu nauczania, z poszczególnych lat, z początku roku akademickiego. S. Trzebiński, dz. cyt., s. 13, 391-393, 397, 402; W. Jakowicki, Sprawozdanie z Wydziału Lekarskiego USB 1929/1930, „Pamiętnik Wileński Towarzystwa Lekarskiego” 1930, R. V, z. 4-5, s. 384; K. Opoczyński, Sprawozdanie Wydziału Lekarskiego USB za rok 1930/1931, „Pamiętnik Wileński Towarzystwa Lekarskiego” 1931, R. VI, z. 5, s. 415; W. Jasiński, Sprawozdanie z Wydziału Lekarskiego USB za rok 1931/1932, „Pamiętnik Wileński Towarzystwa Lekarskiego” 1932, R. VIII, z. 4-5, s. 326; S. Schilling-Siengalewicz, Sprawozdanie z działalności za 1932/1933, „Pamiętnik Wileński Towarzystwa Lekarskiego" 1933, R. IX, z. 6, s. 593; W. Jasiński, Sprawozdanie z Wydziału Lekarskiego na rok 1933/1934, „Pamiętnik Wileński Towarzystwa Lekarskiego” 1934, R. X, z. 5-6, s. 388. M. Reicher ,Sprawozdanie z Wydziału Lekarskiego na rok 1934/1935, „Pamiętnik Wileński Towarzystwa Lekarskiego” 1935, R. XI, z. 4-5, s. 259; S. Hiller, Sprawozdanie z Wydziału Lekarskiego za rok 1936/1937, „Pamiętnik Wileński Towarzystwa Lekarskiego" 1937, R. XIII, z. 4, s. 329; K. Pelczar, Sprawozdanie z działalności Wydziału Lekarskiego USB, w roku 1937/1938, „Pamiętnik Wileński Towarzystwa Lekarskiego" 1938, R. XIV, z. 4, s. 341. 
Kariery naukowe kobiet na Wydziale Lekarskim USB w Wilnie...

Od roku akademickiego 1929/1930 zaprowadzono egzamin konkursowy, zwracając uwagę na poziom i zasób wiedzy u kandydatów. Zasadniczym elementem weryfikacji na Wydziale Lekarskim, prócz poświadczenia o zdanej maturze, był egzamin pisemny z fizyki i chemii. Sprawdzano także możliwości percepcji, umiejętność streszczenia wykładu, ale i przygotowania tekstu - podyktowanego kandydatom $\mathrm{w}$ jednym $\mathrm{z}$ wybranych języków obcych, tj. angielskim, francuskim czy niemieckim. Na oddziale farmaceutycznym za podstawowy uznano egzamin $\mathrm{z}$ botaniki i chemii ${ }^{24}$.

\section{Efektywność nauczania a uzyskiwane uprawnienia zawodowe}

Jeżeli chodzi o przebieg, efektywność nauczania, tempo uzyskanych kwalifikacji z uwzględnieniem podziału na płeć, brak jest pełnej dokumentacji i analizy sytuacji na wileńskim wydziale. Na podstawie szczątkowych materiałów można jedynie przypuścić, że kobiety stanowiły $1 / 3$ studiujących, którzy uzyskiwali dyplom lekarza. Jednak dane potwierdzające ten fakt posiadamy dopiero z lat 30. XX w. Problemem jest jednak ocena skuteczności i terminowego zakończeniu studiów przez tę grupę ${ }^{25}$. Chociaż wydaje się, że sytuacja w zakresie liczby kończących studia z biegiem lat normalizowała się, większość podejmujących naukę kobiet kończyła studia. Absolwentki także tej uczelni zasilały polskie lecznictwo, osiągając ogółem stan 25\% kobiet zatrudnionych $\mathrm{w}$ tej profesji w okresie międzywojennym. Aczkolwiek panuje również przekonanie, że kobiety studiujące $\mathrm{w}$ tym czasie na większości polskich uczelni wykazywały się niższą niż mężczyźni efektywnością w nauce. Częściej miały przerywać kształcenie, w rezultacie w niższym procencie uzyskiwały dyplomy ukończenia studiów ${ }^{26}$. Stwierdzenie to nie sprawdza się jednak w przypadku farmacji, gdzie

24 Tamże.

${ }^{25}$ Danych w tym względzie dostarczają sprawozdania uczelniane z lat 1927-1937, ale także poszczególnych placówek, które jednak wymagają bardziej szczegółowej analizy. Por. m.in. Sprawozdanie 1927-1928, Stany kadrowe Zbiory Specjalne Lietuvos Mokslu Akademijos Virublevkiu Bibloteka, dalej Zb. Spec. LMAVB, sygn. F.98/568, k. 3-10; Sprawozdanie za rok 1929/1930 rektora prof. dr Cz. Falkowskiego, LMAVB, sygn. F.98/574, k. 10-13; Sprawozdanie... 1933/1934, „Pamiętnik Wileński Towarzystwa Lekarskiego” 1934, r. 10, z. 5-6, s. 388; Sprawozdanie... za rok 1936/1937, „Pamiętnik Wileński Towarzystwa Lekarskiego" 1937, r. 13, z. 4, s. 329.

${ }^{26}$ J. Kolbuszewska, dz. cyt., s. 112; za: J. Halbersztadt, Kobiety w murach Uniwersytetu Warszawskiego 1915-1939, [w:] A. Żarnowska, A. Szwarc (red.), Kobieta i kultura. Kobiety wśród twórców kultury intelektualnej i artystycznej $w$ dobie rozbiorów i niepodległym państwie polskim, t. IV, Warszawa 1996, s. 111-112, 113-115. 
dominowały wśród absolwentów, uzyskując tytuł magistra. Był to efekt zwiększonej liczby kobiet uczących się na tym kierunku, o czym już wspominano. Dodać należy, że podstawą do uzyskania stosownego tytułu ukończenia studiów wyższych była ustawa z 1920 r. o szkołach akademickich $^{27}$. Na jej mocy po odbyciu przeszło pięcioletnich studiów i zdaniu wymaganych egzaminów uzyskiwano dyplom lekarza, a po obronie rozprawy - tytuł doktora medycyny ${ }^{28}$. W przypadku zaś farmacji po trzyletnim kształceniu absolwent otrzymywał tytuł magistra, wtedy jeszcze bez możliwości ubiegania się w kraju o stopień naukowy doktora. Na podstawie zachowanej uczelnianej sprawozdawczości można też przypuszczać, że w przypadku lekarzy funkcjonował na wydziałach lekarskich, i to jeszcze w połowie lat 20., model dawnego systemu nadawania stopni, tj. doktora wszech nauk. Jednocześnie na mocy już nowej ustawy z 1920 r. istniała możliwość ubiegania się o stopień doktora medycyny. Konieczne jednak w tym przypadku było napisanie i obrona dysertacji doktorskiej. Funkcjonujący w tym zakresie dualizm, jak pisze Stanisław Trzebiński, na mocy co prawda pewnego prowizorium początkowego okresu kształcenia, wywoływał opór kadry akademickiej, przynajmniej w wileńskiej uczelni. Potwierdza to sprzeciw władz Wydziału wyrażony 11 listopada $1928 \mathrm{r} .{ }^{29}$ Dowodem poświadczającym stan pewnej anomalii było wydanie w roku akademickim 1926/1927 32 dyplomów doktora wszech nauk, ale i 16 dyplomów doktora medycyny obronionych $\mathrm{w}$ wileńskiej uczelni ${ }^{30}$.

W 1927 r. obroniła też dysertację na tym Wydziale, na nowych zasadach, Janina Hurynowiczówna ${ }^{31}$. Podstawą była rozprawa pt. Wpływ insuliny na uktad nerwowy $y^{32}$. Była to zapewne jedna z pierwszych kobiecych obron doktorskich, aczkolwiek nie jedyna w tym czasie. Pojawiają się też nazwiska innych lekarek, które w drugiej połowie lat 20. XX w. zapewne obroniły prace doktorskie, o czym mogą świadczyć

27 Ustawa nr 494 z dn. 13 VII 1920 r. o szkołach akademickich, DzU RP nr 72 z 10 VIII $1920 \mathrm{r}$.

28 Pierwszy dyplom doktora medycyny uzyskał w dniu 24 XI 1924 r. Stefan Bagiński, asystent Katedry Histologii tegoż Wydziału. S. Trzebiński, Wydział Lekarski... Odbitka z Księgi pamiątkowej ku uczczeniu 350 rocznicy założenia Uniwersytetu Wileńskiego, Wilno 1931.

29 Tamże, s. 25.

30 Tamże, s. 19.

31 Janina Hurynowiczówna (1894-1967). A. Śródka, Uczeni polscy XIX-XX stulecia, t. II, Warszawa 1995, s. 70-71; S. Pużyński, Leksykon psychiatrii, Warszawa 1993, s. 556.

32 J. Hurynowiczówna, Wpływ insuliny na układ nerwowy, „Rozprawy na stopień doktora medycyny”, Wilno 1927, Towarzystwo Wydawnicze Pogoń. UVB Facultas Medica Dissertationes Inauguralis Nr 9, Zbiory Specjalne, Główna Biblioteka Lekarska, sygn. 2156871. 
ówczesne awanse na uczelni. Podejrzewać można, że wśród tej grupy mogła być pediatra Jadwiga Niepokojczycka ${ }^{33}$. Druga połowa lat 20. była zatem początkowym okresem rozwoju naukowego kobiet. Dodać jednak należy, że pierwszą kobietą tego Wydziału, która doktoryzowała się, co prawda za granicą w Nancy, była Matylda Chorzelska absolwentka I kursu z farmacji z $1923 \mathrm{r}^{34} \mathrm{~W}$ zakresie podejmowanych prac doktorskich były też reprezentowane i inne dziedziny nauk medycznych, jak np. okulistyka, mikrobiologia, ale i historia medycyny. W przypadku tej ostatniej dziedziny dysertacja obroniona została przez A. Śmigielską-Kowalską ${ }^{35}$. Trzebiński wymienił też doktorat z filozofii i to już z 1925 r., uzyskany przez Kazimierę Urbanowiczównę - pracownika Zakładu Biologii Ogólnej ${ }^{36}$. Dokładne jednak ustalenie liczby kobiet, które pozyskały te stopnie naukowe na mocy nowej ustawy, wymaga dalszych badań. Z ustaleń prof. Wiesława Makarewicza wynika, że do końca istnienia uczelni, czyli do połowy grudnia 1939 r., łącznie 83 osoby obroniły swoje dysertacje ${ }^{37}$. Aczkolwiek może się wydawać, że liczba ta nie jest pełna, co w pewnym sensie potwierdza stan kadr pracowników poszczególnych zakładów czy katedr, gdzie większość osób legitymowała się stopniem doktora (przynajmniej z tytułem figurującym przy nazwisku). Dotarcie do wszystkich ${ }^{38}$ prac jest dziś trudne, jednak nie jest to niemożliwe. Wykazy czy notki dotyczące tytułów obronionych dysertacji na Wydziale Lekarskim USB, zgromadzone za pośrednictwem Stanisława Konopki, znajdują się w zbiorach specjalnych GBL. Informacje w tej kwestii przytacza też, czasem pośrednio, prasa lekarska, a zwłaszcza „Pamiętnik Wileński Towarzystwa Lekarskiego". Materiały tam zamieszczone mogą dać także odpowiedź $\mathrm{w}$ sprawie kolejnego w hierarchii naukowej stopnia, jakim była w tym czasie docentura. Przypuszczać można, że pierwsze habilitacje kobie-

${ }^{33}$ „Po-adiunkt” w Klinice chorób dziecięcych od 1 XI 1923 r., po roku, tj. 18 stycznia (1924 r.), została zatrudniona już jako adiunkt. LCVA sygn. 175/3 IX B 17, k. 57, 75.

${ }^{34}$ S. Trzebiński, Wydział Lekarski... Odbitka..., dz. cyt., s. 30.

${ }_{35}$ K. Pelczar, Sprawozdanie z działalności Wydziału Lekarskiego USB 1937/1938 (XIX rok działalności Wydziału), „Pamiętnik Wileński Towarzystwa Lekarskiego” 1938, R. XIV, z. 4, s. 342. Tematem doktoratu A. Śmigielskiej-Kowalskiej było: Dzieje Katedry Anatomii w dawnym Uniwersytecie Wileńskim i Akademii Medyko-Chirurgicznej w latach 1777-1842, „Disserationes Inaugurales -Universitas Vilnensis Bartoreana Facultes Medica 1938”; A. Žalnora, Stanistaw Trzebiński and his Research in Philosophy of Medicine in Vilnius..., „Medycyna Nowożytna. Studia nad Kulturą Medyczną” 2017, t. 23, z. 2, s. 112.

${ }^{36}$ S. Trzebiński, Wydziat Lekarski... Odbitka..., dz. cyt., s. 39.

${ }^{37}$ W. Makarewicz, O wydziale Lekarskim USB, „Gazeta AMG” 2016, nr 3(44), s. 45, http://tv.task.gda.pl/?p=2642.

${ }^{38}$ A. Śródka, dz. cyt. 
$\mathrm{ce}^{39}$ miały miejsce we wczesnych latach 30 . XX w. W grupie habilitowanych w tym czasie pojawia się nazwisko J. Hurynowiczównej ${ }^{40}$, która już po trzech latach od doktoratu uzyskała ten tytuł. Podstawą była publikacja z roku 1929: Nerwy interaktywne w świetle badań metoda chronaksji. Doceniono też jej dorobek naukowy, a szczególnie prace w zakresie pomiarów pobudliwości układu naczyniowo-ruchowego. Dla porównania warto też odnotować habilitacje męskich pracowników naukowych, które odbywały się na tym Wydziale już od drugiej połowy lat $20 .{ }^{41}$

\section{Awanse - struktura zatrudnionych}

Analiza dokumentacji dotycząca funkcjonowania poszczególnych zakładów, katedr czy klinik pozwala też prześledzić drogi awansu w zakresie pełnionych przez kobiety funkcji. Według Adama Wrzoska, pierwszą kobietą na stanowisku naukowym była Marja Krahelska-Tołwińska, zaangażowana już od roku 1919 w Zakładzie Biologii USB ${ }^{42}$. Sposób naboru pracowników do USB na niższe stanowiska naukowe, określane jako „pomocnicze siły naukowe” ${ }^{43}$, w przeciwieństwie do wyższej kadry jest dotąd mało rozpoznany. Jak wiadomo, stanowiska szefów poszczególnych zakładów czy katedr obejmowali doktorzy ze stosownym dorobkiem. Obowiązywała w tym względzie zasada konkursów, co potwierdza dość bogata dokumentacja uczelniana ${ }^{44}$. Natomiast kariery niższej kadry możemy śledzić jedynie na podstawie dość ograniczonej w te informacje sprawozdawczości wydziałowej, czasem katedr z poszczególnych lat ${ }^{45}$.

Problemem jest także miejsce ukończonych studiów, a szczególnie dotyczy to pierwszych lat funkcjonowania USB. Wiadomo jednak, że głównie z powodu braku własnej wykształconej kadry musiano

39 Pierwszą kobietą w Polsce, która pomyślnie zakończyła, w 1920 r., procedurę habilitacji z zakresu filozofii, ale i medycyny, była Helena Gajewska. Habilitacja ta odbyła się na Wydziale Lekarskim Uniwersytetu Jagiellońskiego. J. Kolbuszewska, dz. cyt., s. 111.

${ }^{40}$ LCVA sygn. 175/3 IX B, 89, k. 34. A. Śródka, dz. cyt.

4117 marca 1926 r. przyjęto regulamin nadawania habilitacji. S. Trzebiński, dz. cyt., S. 21.

42 A. Wrzosek, Wskrzeszenie Uniwersytetu Wileńskiego w 1919, [w:] Księga pamiątkowa ku uczczeniu CCCL rocznicy założenia i X wskrzeszenia Uniwersytetu Wileńskiego, Wilno 1929, s. 44.

${ }^{43}$ K. Pelczar, Sprawozdanie z działalności Wydziału Lekarskiego USB 1937/1938, „Pamiętnik Wileński Towarzystwa Lekarskiego” 1938, R. XIV, z. 4, s. 335.

${ }^{44}$ Por. np. w sprawie obsadzenia II Kliniki chorób wewnętrznych, LCVA, sygn. 175/ 3IXB 81, k. 1-4.

45 Dokumentacja Kliniki pediatrycznej LCVA, sygn. 175/3IXB 80. 
Kariery naukowe kobiet na Wydziale Lekarskim USB w Wilnie...

Tabela 3. Kobiety jako pomocnicze siły naukowe Wydziału Lekarskiego USB w latach 1920-1929 w liczbach

\begin{tabular}{|c|c|c|c|c|}
\hline Lp. & Katedry/zakłady & $\begin{array}{l}\text { Lata } \\
1920-1925\end{array}$ & $\begin{array}{c}\text { Lata } \\
1926-1929\end{array}$ & $\begin{array}{c}\text { Wszyscy } \\
\text { zatrudnieni } \\
\text { do } 1929 \text { (stan) }\end{array}$ \\
\hline 1. & Zakład Anatomii Opisowej & 1 & Brak & 13 \\
\hline 2 & Zakład Histologii & 3 & 2 & 12 \\
\hline 3 & $\begin{array}{l}\text { Seminarium Historii } \\
\text { i Filozofii }\end{array}$ & Brak & $\begin{array}{c}2 \text { na } 1 / 2 \text { et. } \\
+2\end{array}$ & 4 \\
\hline 4 & Zakład Chemii Fiz. & Brak & Brak & 1 \\
\hline 5 & Zakład Fizjologii & Brak & Brak & 9 \\
\hline 6 & Zakład Biologii Ogólnej & 2 & Brak & 4 \\
\hline 7 & Zakład Patologii Ogólnej & Brak & 3 & 6 \\
\hline 8 & $\begin{array}{l}\text { Zakład Anatomii } \\
\text { Topograficznej }\end{array}$ & Brak & Brak & 3 \\
\hline 9 & $\begin{array}{l}\text { Zakład Anatomii } \\
\text { Patologicznej }\end{array}$ & Brak & 1 & 7 \\
\hline 10 & Zakład Bakteriologii & Brak & 1 & 2 \\
\hline 11 & Zakład Farmakologii & Brak & Brak & 7 \\
\hline 12 & Zakład Higieny & Brak & 1 & 6 \\
\hline 13 & Zakład Medycyny Sądowej & 1 & 2 & 4. \\
\hline 14 & $\begin{array}{l}\text { I Klinika Chorób } \\
\text { Wewnętrznych }\end{array}$ & 1 & 2 & $\begin{array}{c}10+3 \\
\text { hospitantów }\end{array}$ \\
\hline 15 & $\begin{array}{l}\text { II Klinika Chorób } \\
\text { Wewnętrznych }\end{array}$ & 2 & 3 & $8+6$ hosp. \\
\hline 16 & Zakład Chirurgii Ogólnej & 1 & Bz. & 1 \\
\hline 17 & Klinika Chirurgiczna & & 2 & $6+14$ hosp. \\
\hline 18 & $\begin{array}{l}\text { Klinika Ginekologiczno- } \\
\text {-Położnicza }\end{array}$ & Brak & 2 & $4+4$ hosp. \\
\hline 19 & Klinika Dziecięca & 1 & 4 & 13 \\
\hline 20 & Klinka Neurologiczna & 1 & 1 & 4 \\
\hline 21 & Klinika Psychiatryczna & 1 & 1 & 8 \\
\hline 22 & Klinika Dermatologiczna & Brak & 1 & 8 \\
\hline 23 & Klinika Oczna & 2 & 2 & $\begin{array}{c}6+10 \\
\text { wolontariat }\end{array}$ \\
\hline 24 & Klinika Otolaryngologii & Brak & Brak & $4+$ hosp. \\
\hline 25 & Zakład Stomatologii & Brak & Brak & $1 / 2$ etatu \\
\hline 26 & $\begin{array}{l}\text { Zakład Farm. i Hodowli } \\
\text { Roślin }\end{array}$ & Brak & Brak & 5 \\
\hline 27 & Zakład Chemii Farm. & 1 & Brak & 3 \\
\hline & Razem osób & 17 & 32 & 158 \\
\hline
\end{tabular}

Źródło: obliczenia własne na podstawie sprawozdawczości z lat 1920-1929 według S. Trzebińskiego, Wydział Lekarski... Odbitka..., dz. cyt., s. 30-87. 
obsadzać poszczególne stanowiska osobami, które ukończyły studia poza uniwersytetem wileńskim. Stan ten utrzymywał się do połowy lat 20. XX w. ${ }^{46}$ Dość popularnym miejscem, z którego rekrutowano czy wywodziły się kobiece kadry naukowe, zwłaszcza w początkowym okresie istnienia Wydziału, był Petersburski Żeński Instytut Medyczny $^{47}$, a także Uniwersytet Jagielloński w Krakowie ${ }^{48}$.

Od połowy lat 20. przeważają już absolwentki rodzimego Wydziału, które rozpoczynały wtedy pracę na uczelni, ale i poza Uniwersytetem, pełniąc różne funkcje. Najczęściej działalność naukowo-dydaktyczną rozpoczynano od sprawowania funkcji młodszego asystenta. Pełniona ona była najczęściej przez rok, czasem nawet przez pięć lat, po czym bywało, że następował awans na tzw. starszego asystenta ${ }^{49}$. Dodać należy, że już od początku funkcjonowania Wydziału kobiety obsadzono w 12 zakładach, katedrach czy klinikach na łączną liczbę zorganizowanych 27 placówek ${ }^{50}$. Jednak liczebność zatrudnionych w poszczególnych jednostkach była ograniczona, zwłaszcza do połowy lat 20. Kształtowała się przeciętnie od jednej do trzech osób zatrudnionych, jak miało to miejsce w przypadku Zakładu Histologii. Struktura zatrudnienia wynikała zresztą z możliwości i specyfiki tych placówek, a także po części z konkretnych zainteresowań tam pracujących. Ponadto zapewne też z ukształtowanych wyobrażeń o tzw. kobiecych predyspozycjach czy nawet ich możliwościach naukowych w medycynie. Notowano zresztą sporą fluktuację, zmiany na stanowiskach zwłaszcza w klinikach. Powody były podobne do dzisiejszych: przekroczony czas rozwoju naukowego, a także indywidualne powody poszczególnych osób ${ }^{51}$.

${ }^{46}$ R. Mienicki, Pierwsze dziesięciolecie USB w Wilnie, [w:] Księga pamiatkowa ku uczczeniu CCCL rocznicy założenia i X wskrzeszenia Uniwersytetu Wileńskiego, Wilno 1929, s. 123, 145.

47 M.in. absolwentką tego Instytutu była dr Halina Jankowska (1890/1892?-1944). Od 1 I 1924 r. starszy asystent w Klinice Psychiatrycznej Wydziału Lekarskiego USB. Ponadto Instytut ten ukończyła wspomniana powyżej Kazimiera Urbanowiczówna z Zakładu Biologii Ogólnej. S. Trzebiński, Wydział Lekarski... Odbitka..., dz. cyt., s. 39; S. Pużyński, dz. cyt., s. 556. Petersburski Żeński Instytut Medyczny powstał w 1897 r., nazywany był w skrócie Instytutem Medycznym lub Instytutem Lekarskim. F. Nowiński, Polscy studenci na wyższych uczelniach Petersburga $w$ XIX $w$. Tekst wystąpienia na Międzynarodowej Konferencji: Polski Petersburg, Historia i pamięć, 10-14 IV 2013, www.polskipetersburg.pl/.../Polscy_studenci_na wyższych_uczelniach_Petersburga...

48 R. Mienicki, dz. cyt., s. 123.

49 Tamże, s. 30-87. Według zaleceń ministerialnych, w tym m.in. pisma z 29 marca 1927 r., podział z wydzieleniem obowiązków asystentów młodszych i starszych miał zostać zniesiony. W praktyce wydaje się, że nadal obowiązywał. LCVA, sygn. 175/ 3IX B 81, k. 114.

50 Por. tabela 3.

51 S. Trzebiński, dz. cyt., s. 54. 
Ze wszystkich wspomnianych 27 uczelnianych placówek, przynajmniej do roku 1929, kobiety, jako pomocnicze siły naukowe, nie były zatrudnione w siedmiu zakładach, w tym: Chemii Fizycznej, Fizjologii, Anatomii Topograficznej, Farmakologii, Farmakognozji i Hodowli Roślin, Stomatologii ale i w klinice Otolaryngologii ${ }^{52}$. Jak już wspomniano, kobiety, jako personel pomocniczy, pracowały w placówkach już od początku lat 20. XX w., największy jednak przyrost zatrudnionych miał miejsce $w$ klinikach $w$ drugiej połowie tych lat ${ }^{53}$. $\mathrm{Na}$ etatach naukowych w 1929 r. odnotowano 32 nowe siły (nie licząc wcześniej zatrudnionych i zwolnionych do tego czasu). Łącznie do wspomnianego roku pracowało (czy pojawiło się) 49 kobiet na przeszło 158 zatrudnionych ${ }^{54}$. Po roku 1929 sytuacja ta ulegała zmianie i w kolejnych jednostkach zatrudniano je na stanowiskach naukowych. Miała też miejsce wymiana osób tu pracujących. Aczkolwiek określenie pełnego stanu nowych sił kobiecych w strukturach akademickich i to w kolejnych latach, aż po rok 1939, wymaga dalszych badań. Stwierdzić jednak można, że w zależności też od profilu jednostki czy znaczenia w kształceniu studentów zatrudniano do tych zadań odpowiednią liczbę osób, przy czym w zakładach teoretycznych, jak np. anatomii opisowej, była ona dość ograniczona. I tak, w zakładzie tym na łączną liczbę 13 osób pracowała jako jedyna kobieta $^{55}$ dr Gabryela Nowakuńska - przez pięć lat jako młodszy asystent, po tym czasie uzyskała awans na starszego asystenta ${ }^{56}$. Należy jednak pamiętać o trwającej także w tym i innych zakładach rotacji i zatrudnianiu kolejnych osób, o czym już wspominano. W pierwszym dziesięcioleciu USB, czyli w roku akademickim 1923/1924, pojawiły się też funkcje niepłatnych pracowników wolontariuszy czy hospitantów ${ }^{57}$. Mimo że ich pozycja była podobna to jednak hospitanci byli luźnej powiązani z uczelnią, pozbawieni obowiązku uczestnictwa w zajęciach, poddawania się egzaminom. Bywało bowiem, że rekrutowano ich spośród studentów czy nawet osób, jak się wydaje, niezwiązanych z Uniwersytetem. Od połowy lat 20. często też była to tzw. furtka do rozwoju dalszej kariery naukowej, pracy np. w kate-

\footnotetext{
52 Tamże, s. 30-87.

53 Tamże, s. 46, 63.

54 Por. tabela 3.

55 Dane z 1929 r. Por. tabela 3.

56 S. Trzebiński, Wydział Lekarski... Odbitka..., dz. cyt., s. 31.

57 Pismo z Wydziału Lekarskiego do Senatu USB z dnia 26IX 1923 r. LCVA sygn.
} 175/1 IA 130, k. 49. 
drze $^{58}$. Co, oczywiście, stawało się korzystne dla Wydziału, przynajmniej okresowo, nie tylko ze względów finansowych.

System stopniowego dochodzenia do wyższych funkcji czy stopni naukowych wydaje się na pozór identyczny zarówno dla mężczyzn, jak i kobiet. Gdy bowiem obserwuje się kariery przynajmniej części kobiet, można stwierdzić, że zajmowały one możliwie wszystkie dostępne w tym względzie szczeble stanowisk naukowo-zawodowych. Bywało jednak, że „poznawanie” ich możliwości naukowych, rozpoczynając drogę rozwoju od poziomu młodszego asystenta, skutkujące w końcu awansem, trwało dłużej niż w przypadku mężczyzn. Dotyczyło to szczególnie wspomnianych zakładów teoretycznych Wydziału Lekarskiego. W katedrach czy klinikach o profilu praktycznym proces ten był na ogół krótszy ${ }^{59}$. Jednakże kariera i w tych placówkach w większości kończyła się na szczeblu starszego asystenta, a dalszy rozwój naukowy nie nastąpił. Przykładem jest tu postać dr Zofji Kuncewiczównej z I Kliniki Chorób Wewnętrznych, która po sześciu latach pracy, już jako starszy asystent, „ustąpiła”, jak podano w oficjalnym sprawozdaniu uczelnianym za rok 1927/1928 ${ }^{60}$. Dla niektórych kolejnym etapem kariery była funkcja adiunkta. $Z$ dokumentacji uczelnianej jednak wynika, że tylko nieliczne dostąpiły do objęcia tego stanowiska. Wyróżnić tu można głównie trzy kliniki niezabiegowe, gdzie kobiecy awans miał miejsce: i tak I Wewnętrzna, gdzie stanowisko, co prawda tylko jako pełniąca obowiązki, objęła w $1928 \mathrm{r}$. dr Helena Cynkutisówna ${ }^{61}$. Ponadto dotyczyło to personelu Kliniki Neurologicznej (sąsiadującej ze wspomnianą Kliniką, dzięki siedzibie w Szpitalu św. Rocha), gdzie w tym samym roku funkcję adiunkta objęła dr Halina Jankowska ${ }^{62}$. Najwcześniej, bowiem już w 1924 r., zaledwie w dwa lata po awansie na starszego asystenta, adiunktem została pediatra dr Jadwiga Niepokojczycka ${ }^{63}$. Wedle danych statystycznych, w drugiej połowie lat 30. na stanie pomocniczych sił naukowych Wydziału Lekarskiego łącznie figurowało 13 adiunktów, od 37 do 38 starszych i od 41 do 43 młodszych asystentów. W wykazie tym jednak nie odnotowano oddzielnej liczby kobiet na tych stanowiskach naukowych ${ }^{64}$.

${ }^{58}$ Por. tabela 3.

${ }^{59}$ S. Trzebiński, Wydziat Lekarski... Odbitka..., dz. cyt., s. 30-87.

${ }^{60}$ Tamże, s. 54.

${ }^{61}$ Tamże.

${ }^{62}$ H. Jankowska wcześniej, tj od 1 IV 1924 r., była zatrudniona w Klinice Psychiatrycznej na stanowisku starszego asystenta. LCVA 175/3 IX B, k. 59.

${ }^{63}$ Por. przyp. 34. LCVA sygn.175/3 IX B 17, k. 57.

${ }^{64}$ K. Pelczar, Sprawozdanie z działalności Wydziału Lekarskiego USB 1937/1938, „Pamiętnik Wileński Towarzystwa Lekarskiego” 1938, R. XIV, z. 4, s. 335. 
Kariery naukowe kobiet na Wydziale Lekarskim USB w Wilnie...

W okresie istnienia USB kobiety nie doczekały się jednak mianowania profesorskiego, a wraz z tym tytułem samodzielnego kierowania placówką naukową, np. katedrą czy zakładem. Aczkolwiek dwie osoby były brane pod uwagę do tej roli. I tak, wspomniana już neuro$\log$ dr Janina Hurynowiczówna ${ }^{65}$ w 1937 r. - z tytułem zastępcy profesora i pediatra dr H. Kaulbersz-Marynowska, która początkowo zastępowała prof. W. Jasińskiego w pełnieniu funkcji kierownika Kliniki Pediatrycznej. W wyniku zapewne dobrze wypełnianych zadań w prowadzeniu Kliniki zaproponowano tej ostatniej udział w konkursie na objęcie stanowiska kierownika katedry ${ }^{66}$. Jednak wynik kwalifikacyjnej, konkursowej procedury nie był dla niej pomyślny ${ }^{67}$. Tymczasem Hurynowiczównej powierzono funkcję kierownika, ale Pracowni Neurofizjologicznej Katedry i Kliniki Neurologicznej, którą sprawowała w latach 1930-1933, a po tym okresie aż do 1939 r. była kierownikiem Pracowni Elektrofizjologicznej Katedry Fizjologii. Podczas swojej działalności zarówno Kaulbersz-Marynowska, jak i Hurynowiczówna prowadziły wykłady dla studentów na uczelni ${ }^{68}$.

Wnioski nasuwają się zatem następujące: kobiety na studiach medycznych stanowiły ok. 25\% ogólnej liczby wszystkich uczących się. Większość z tej grupy, pomimo trudności, kończyła studia i próbowała rozwijać działalność naukową. Do roku 1929 r. zajmowały podstawowe stanowiska akademickie: w przeważającej liczbie zakładów i prawie wszystkich klinik, sprawując funkcję asystentki młodszej lub starszej. Jednak tylko nieliczne $\mathrm{z}$ tej grupy, w liczbie zaledwie trzech osób, awansowały, obejmując stanowisko adiunkta, uzyskując też habilitacje. Wyższy awans $\mathrm{w}$ karierze naukowej i stałe objęcie kierownictwa katedry wraz godnością profesora nie były wtedy jeszcze możliwe. $Z$ wyższych stanowisk naukowych pełniły jedynie funkcje kierowników pracowni. Dotyczyło to jednak tylko pojedynczych osób kobiecej kadry wileńskiego wydziału. Dodać jednak należy, że równocześnie miały one możliwość przekazywania studentom - w formie wykładu - swojego dorobku i osiągnięć.

Analiza ta, pomimo wykorzystanych dość szczątkowych danych, ukazuje długą drogę do sukcesu zawodowo-naukowego kobiet. Czas jednak 20 zaledwie lat nie mógł zmienić środowiskowej, utartej men-

\footnotetext{
${ }^{65}$ LCVA F. 175., ap. 3, IX b nr 89, k. 34. LMAV, Zb. Spec. F 98-574, k. 10.

${ }^{66}$ J. Podgórski, I. Sztachelska, H. Kaulbersz-Marynowska [w:] E. Wilkoszewski (red.), Stownik biograficzny zastużonych pediatrów, z. 2, Warszawa 1990, s. 64. LCVA F. 175 , ap. I ,B b nr 705, s. 40-41, 45-47, 49-50.

${ }_{67}$ Tamże.

${ }^{68}$ A. Środka, dz. cyt., s. 70.
} 
talności „dawnych lekarzy” w zakresie żeńskich karier oraz poznawania ich możliwości naukowych. Mimo to, co należy przypomnieć, udział kobiet $\mathrm{w}$ ówczesnym lecznictwie był już znaczący. Szybszy awans komplikowały też przyjmowane dość sztywne ograniczenia w kwalifikacji na studia, wyznaczające limity, ale i trud finansowy pokrywania kosztów studiów. Nie mniejszą rolę odgrywały zapewne sprawy rodzinne i wydłużający się dla tej grupy czas rozwoju naukowo-zawodowego.

\section{Summary \\ Academic careers of women at the Faculty of Medicine of the Stefan Batory Vilnius University in the interwar period (1919-1939)}

There was a characteristic elevation in the position of women on the territory of Poland after the first World War - not only when it came to acquiring voting rights but also regarding the carrying out of female aspirations related to obtaining professional certifications and necessary qualifications. That period of time is even sometimes shortly referred to as a 'female knowledge rush' where women were taking care of the development of their academic careers.

I want to illustrate this issue using the example provided by the medical faculty of the Vilnius University, one of the several faculties that operated at that university from 1919 to 1939. It is worth emphasizing that the aforementioned faculty foresaw - even as late as the end of the $19^{\text {th }}$ century - a number of restrictions related to women. A woman attending the Medical Faculty was, at the very least, seen as behaving somewhat inappropriate. 